\title{
TWO PARADOXES OF PROJECTION
}

\author{
Whit Blauvelt ${ }^{1}$ \\ Clare E. Mundell ${ }^{2}$
}

\begin{abstract}
AвSTRACT: Recently developed projective models of consciousness and its contents challenge received schemas in which all contents of consciousness are held to be well contained in the skull. Working our way into this from several angles, it becomes evident that there are inconsistencies in how we frame classes of mental contents which are arguably equivalent in being. Particular examples of imagery, of dancing and of words, are brought forward to highlight the clash in our apprehensive assumptions, focusing on possible cognitive as well as psychological costs of such inconsistency. A coherent way to blend the container and projector schemas is pointed out; yet such a blend does not support the standard claim for any kind of purely inner voice, contained but not projected. Conscious reflection may in all instances depend on projection, with reflection in imagery — visual, audible, even tactile and otherwise felt - placed just the far side of what can schematically be grasped as the sensory horizon where, in the space-time just beyond here and now, our imaginative expectations backstop recognition of here-now present things.
\end{abstract}

Keywords: Consciousness. Perceptual projection. Image. Dance. Words.

\section{INTRODUCTION}

Velmans (1996) demonstrates a paradox of projection and containment. While we may take our representations of the world as being contained within the head, in subjective experience our representations are projected into the space of the world as presented. So, Velmans suggests, in a sense the skull is outside, containing all we perceive presented before us. In Velman's paradox the skull is in two places, both what we're projecting out from, and what we're projecting within; the skull both contains the mind, and the mind in

\footnotetext{
${ }^{1}$ Independent Researcher. Bellows Falls, Vermont - United States of America. E-mail: whit@csmind. com

2 Ph.D., Clinical Psychologist at the Northern Light Acadia Hospital, Bangor, Maine - United States of America. E-mail: cemundell@gmail.com
}

http://dx.doi.org/10.1590/0101-3173.2018.v41esp.10.p183 
turn contains our world. Here we focus on a different, yet related, paradox of projection.

We foresee our prospects as well as the world's, including prospective acts of speaking.

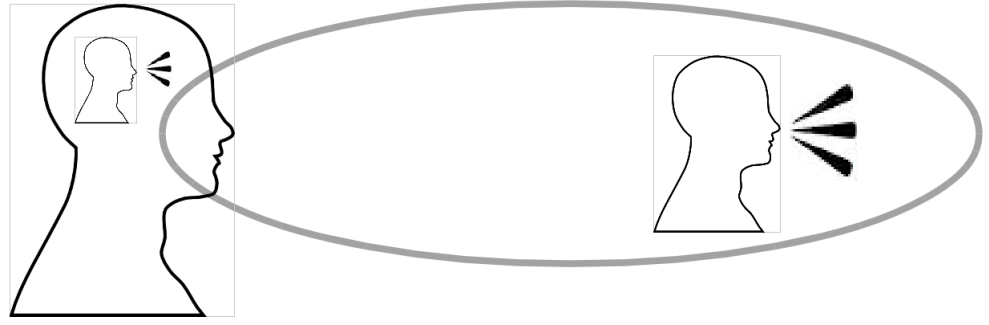

In our normal framing, our prospects are seen ahead of us, forward in world and time, but also in our minds. The single set of prospects is seen as if in two places, because we see it through the blend of these two schemas. Prospects are fore yet in. When we foresee ourselves doing most any action, it's clear to us that an action not yet performed in the world remains in the prospective field.

If we look forward to dancing, it is "in" the mind, but only in the same sense as it is "forward" as a prospect, not yet a real act. When we say that this imagery is "in" the mind, we don't lose sight of its being "forward" - it's not ontologically "here."

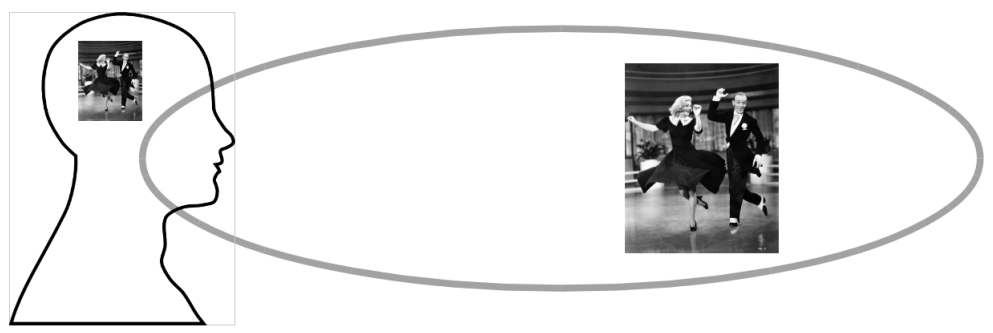

In addition to auditioning the prospects of speech, which when well imagined should sometimes precisely resemble us, do we also experience a directly speaking "inner voice," which is "in" in a sense that does not also essentially place it in the prospective field? Can all "inner speech" be reduced 
to prospective and remembered speech, "in" yet at the same time framed as forward or behind us? Or do we have need of something more, an inner speaker? In addition to voices - ours and others and blends between them - "in" the mind by virtue of being in our prospective field, is there another, separate sort of "inner voice"? If so how would we know it apart? How would we know our projections of its prospects from what it's "really" saying? Can we? Or would what we expect it to say be self-fulfilling, as we confuse the prospect with the absent fact?

Wiley (2016, p. 79) notes a strong correlation in brain damaged subjects between deficits of foresight and lack of inner speech, but takes the correlation as supporting his claim that inner speech is responsible for foresight; here the suggested interpretation of the correlation is in the other direction: foresight is the cause of "inner speech."

\section{SCHEMAS}

Concepts often are drawn from metaphor and analogy (LAKOFF; JOHNSON, 2003; HOFSTADTER; SANDER, 2015). These can become abstracted and generalized into image schemas. Johnson (1990) makes a central example of the container schema. Its origin is evident in humanity's long use of jars and baskets, houses and walled settlements. It shows up today in categories and sets, generally visualized as containers with objects within; although as Lakoff (1990) has shown, categories in our natural languages often take the shape of metaphoric projections from central instances rather than being contained within clear borders.

To know a thing is not just to project it, but to project of it, to predict something of at least its most immediate future. Clark (2015) argues in detail that predictive processing is central to mind. Simple considerations also point to this. To recognize a friend or enemy is to expect consonant behavior from them; to recognize a cup or chair is to see its affordance, our prospective use (GIBSON, 2015); to recognize a stone in the path is to see we might stub our toe. If we schematize our present scene as our container, whose edge is the present time and the space before us up to the edge of what our senses avail, then our recognition, being prospective, extends on beyond, continuous from the edge of scene, containing the expectations which constitute our recognition of the contents of our present location in space and time. 
The boundary of the scene then (which varies among our senses) is never the limit of our awareness. We project beyond the present scene, to the degree we recognize it contents, into their immediate futures. Our understanding of things always extends beyond presence. Awareness participates in prediction. Comprehension of the present scene entails projections beyond it, both immediate and far.

Beyond the immediate scope of the senses, the future extends before us yet at the same time is "in our head." While the duplication of locations here may seem a relatively untroubling contradiction, commonplace even, it can be problematic as ground for more detailed theoretic constructions to have this fault line unexamined beneath them.

\section{Projection}

While each thing grasped within our senses entails an imaginative projection, we also imagine well beyond present occurrence. Occurrent imagery is arguably within the present horizon, in the sense that it is a present fact that it is now currently imagined. Yet these projections are beyond the present sensory horizon in space-time, not real in the sense that directly sensed aspects of the present scene are. Where real things resist our imagination, imagination is more accommodating to itself (NEWTON, 1996).

Where the container schema leads to a confused picture here, the projection schema can afford clarity. Projection has been less central to quotidian human existence than containment, in consequence not so widely used in our metaphors. Campfires have projected light since we first mastered them; those around the fire have long been familiar with projecting imagination into the flames. Empedocles and other ancient Greeks even believed we see by light projected from our eyes. More recently it is only with the advent of the camera obscura, and subsequently cinema, that projection has attained everyday commonplace, ever moreso with our multiplying video screens. Being relatively recently ascendant, the projection schema has yet to become, if ever it will be, as integral to our understanding as the container.

Is the better model of knowledge based on the schema of containing things well, or of projecting them well? The long history of science is often one idealizing containment, sorting things in the right jars, labeled with the right category names. Yet those categories, in practice, can take the 
form of tree-structured projection, as in the diagrams of an evolutionary tree of life. The tree, suggestively a projective structure with its branches analogous to the branching paths which have long characterized the world we navigate (BLAUVELT, 1999), was central to the myth of an Eden safely contained in its walls, even while the tree's projective implications, spoken for by a serpent twined in its branches, was held to account for our exile (GREENBLATT, 2017).

\section{Plans}

Prospects branch ahead of us. In some prospects, language is central: a campaign speech, a lecture, an excuse, a command. In others, language is secondary, elements of speech within broader prospects, or aspects of yet other prospects which have a view of the central prospects considered, "about" them as a vine (or snake) is about a branch. We imagine advice along our branching paths; we imagine critical reaction. The "aboutness" of language falls out naturally from the branching structure of possibilities, fruit of that tree.

When in the course of planning we map possibilities, we can construct a larger map by forming alternative plans. However this will not happen if, in forming a plan, we come immediately to intend it. A typical plan might consist of a sketch of the action (usually visual), a name of the action (usually audible - so we can say what we are doing), and a feel for the action (feels right, feels necessary, an apprehensive feeling about — also a feeling of the body prepped properly to undertake it). An imagined self-voice which thus accompanies planning, when taken to be one's own self really speaking now, might fool us into halting the further turnings of mind, substituting its faux directive for free action in light of a range of well-projected prospects.

That we would wish to say something — in our public language — to ourself entails several metaphysical presumptions which explaining voices as part of projections does not. It presumes that there is an autonomous unit within the self which, on its own, is prepared to decide what to say. This is not a problem in speaking with others - we speak as ourselves, not as a part. The self-within-self, the homunculus (RYLE, 1949), is presumed to be separated enough from the rest of us that it has a unique point of view, and can only share this by talking from over there - where it is - to the rest of ourself over here. If it were in the same place as we are, there would presumably be nothing to say; we would already share its perspective. 
In the projection schema, imagination begins at the immediate sensory horizon, engaged there in recognition of things - their promises, threats, and consequences - based on projection from memories of analogous experience. Imagination then continues on farther beyond the sensory horizon. In both the near and farther scopes, the subjective perspective is a projective one. What's imagined, both of the immediate world and beyond, is primarily out there. Only secondarily, in what is perhaps our over reliance on the container schema, can we also claim, with some contradiction, that it's also all within the skull. Self-reflection is consequent to a projection of futures and spaces, each featuring our point of view as source. There may be no more direct view of self, no reflection without projection.

\section{Considerations}

The projection and containment schemas can be blended, as when a vase contains stems, projecting from it. (On blending of mental spaces, see Fauconnier, 1997). Consider explaining how words contain meaning, versus how words serve meaning in projection. If words should be understood as containers with meaning within them, this is quite a mystery. By contrast, viewed as objects among others in projection, aboutness is inherent in words' situatedness. As we comprehend things on the sensory horizon, while their primary prospects are their own, they are prone to suggest, for those like us who often encounter descriptions in our world, projections of prospective words about (in the sense of in the close vicinity of) the primary prospects. The words then, in a projective scheme, do not so much contain the meaning of the things. The primary prospects of the objects in our present focus - of the things themselves - contain by associative projection secondary prospects, which for language-using creatures "contain" what can be said about them, in much the same way as a vase contains stems projected in an array from it. We might even leave aside the container schema entirely here, with little loss of clarity, and see the aboutness as simply secondary projections branched sideways from the primary projection of the prospects as themselves, naked of language.

It goes without saying that language occurs within the sensory horizon too. Things can be imaginatively projected about words, just as words can be projected into imagined space in the vicinity of things. Yet the core value of things is generally in the primary prospects of those things themselves, 
rather than the secondary prospects of words projected about them, except where words themselves are the objects of primary focus. Words reflect our comprehension of the things they are projected about; they do not constitute it. The core of meaning, as captured in our predictive apprehension is, despite the term, only secondarily "dictive." The rock in the path means our toe about to stub, not our exclamation on doing so.

Velmans (1996) argues that scientists' favorite theories often leave out the subjective fact that we experience the world as out there, not in our heads. But there is an exception, an inconsistency in our subjective experience (in our current culture), which may motivate those scientists' use of the container schema rather than the projection schema in their conceptualizations: language, as thought, is commonly subjectively experienced as being within our skulls (FERNYHOUGH, 2016).

The paradox in this common folk view, as well as its scientific offshoots, can be seen by comparing our understandings of "inner" speech with other "inner" imagery. Our folk paradigm of imagery in general is projective; what we imagine we simply take to be beyond the present scene. Even when we would also, if asked, locate the whole of it within our heads, our common contextualiation of the subjects of imagination has them elsewhere in space, time, or both - out in a projected space. Meanwhile our folk paradigm of "inner speech" uses the container schema exclusively, seeing it as within our heads as grain might be contained in a jar. Where then should we place images of speech, such as when we are imagining a future scene containing speech acts?

Any sample of "inner speech" can be contextualized as forward, in accordance with the projection schema, without loss of meaning. (For an example, try it.) Given that, is something lost when projected speech we have imagined is instead solely contextualized as contained in the head? While easily imaginable, this framing places "inner" speech directly in the center, within the sensory horizon, while other items in projected imagination remain at and beyond the horizon. Since our conscious attention to things before the senses essentially involves imagination of their near future, when we believe that some talk in mind is more than just imagery of speech, and that this real and present inner speech is revealed to us via an introspective sense - as if through a window directly into the mind - we naturally project what it may say next. Doing so, we run the risk of mistaking that in turn for more introspected (directly experienced, not merely projected in imagination) 
speech, and so on. Beck's (1979) "cognitive therapy" makes interrupting such loops central to its statistically-successful clinical method.

This is not to argue that imagery of speech is not, as it occurs, present. Instead this questions the nature of its presence. Is this speech present in the way of being contained within our skulls as our brains are, or only present imaginatively, as prospects projected from our minds might be? Might all imagery, including imagery of speech, belong to what Descartes (2017) called rex extensia (having extension in space) or is there some "inner speech" which, despite the projected situation of other imagery, is best conceived as contained in its own realm, rex cogitans? The difference in regards to projection may be clarified by comparing this to our common understanding of imagery of dance.

\section{WHEN WE DANCE}

If we dance in the world, we truly dance; if we speak in the world, we truly speak. The quality of those performances is a secondary question. But the performance is a fact in the world. When we imagine dancing, we truly imagine; when we imagine speaking, we truly imagine. Imagination is a fact of conscious minds in the world. To consciously know what something is requires that we have some capacity to imagine its behavior and future. Conscious comprehension requires imagination, as does conscious action.

There is a difference between imagining and doing. To imagine dancing, or speaking, does not require there be an inner dancer or inner speaker. If we mistake some of that imagination for a real, present performance, however, then we mistake the inner dancing or speaking for the performative act of an inner dancer, or an inner speaker. That mistake, I am arguing, is the origin of the mistaken notion of a self-in-self, of an inner speaker, a homunculus, who can tell us what we "really" think. Language is the only thing we imagine where we commonly risk confusing the imagined with the actually occurring.

There is no more an inner speaker than there is an inner dancer. There's poetic truth, but not literal truth, in speaking or seeing ourselves as if these were real. This confusion about the "inner speaker," as a presumed homunculus, is a good candidate for the origin of the "false ego" that many people, East and West, are concerned with transcending. It's subtle, though. 
Yes, imagination actually occurs, but as imagination. This is a difference we have no trouble recognizing when it is dancing we imagine.

It is possible to think, quite clearly, in language and vision (and other senses) conjoined, while maintaining the perspective from which all of the language in thought is seen as just imagined, rather than as speech acts within the self. This is not advocating against language, or against audition, only arguing for not taking instances of speech, when imagined, as having extra reality, more reality than what else we envision — for keeping "inner" audition in common perspective as imagination.

We can have images of words. Images of words are different from words actually being experienced, in the same way images of a dancer are different from a dancer actually being experienced. When we mistake imagery for experience, it is often a serious mistake. It is no special concern when images of speech acts and images of other sorts of acts are taken equally as imagined, or experienced in the world as equally real. I am concerned when images of speech are taken as real inner speech acts (by an implied inner speaker) (SEARLE, 1970) in a way that we never take images of dancing as a real inner dancer. The latter is simply nonsense. The former, really, is too. And acceptance of the implied inner speaker as real may be the origin of the "ego" error that much of Eastern wisdom warns against. It's an asymmetry in the ontological framework by which we comprehend ourselves, when we confuse but a single category of imagery — the linguistic — for present experience. Only when this generation of the false self is eased, can a clearer view of the realities of self — subtle and complex as they are - emerge.

\section{WILL?}

If we believe we have an inner speaker, then by what mark can we differentiate the imagination of what we might say from really saying it inwardly? That question does not occur for the other senses. An "inner dancer" or an "inner painter" is obviously nothing other than imagining dancing, imagining painting. Yet we confuse an "inner speaker" for something more solid than imagining. That confusion holds audition apart from the other senses. Then it does not compound so freely with them into what the Scots called the "common sense" (REID, 2000) or the "inner sense" (HUTCHESON, 2004), the emergence of deeper sensibility which commingles the individual, outward senses, perhaps at times to transcend them. 
Anything we can work out in language, we can work out in its prospects. About the only thing we can't do, if (public) language "inside" is just prospects, not someone speaking, is tell ourselves what to do. If we truly can not tell the prospects from the speaking, we can not know which is the order, and which is just the prospect of it. But most of us have bosses. Doing our jobs consists in part of accurately foreseeing what the boss would say to do. While on the job, once we have seen that prospect, broader prospecting - daydreaming - is not "in order." It is but a short step from that to the notion that doing your own "will" consists in a similar "self-obedience," or "self-discipline," substituting your own voice for the boss's.

If we see prospects of ourselves down various branches of the paths ahead, providing various reflections in prospective speech, without believing as a matter of ontology that there's a separate inner voice, then we should hesitate to take such voices as epistemic evidence of our true will or intention. The flip side of this is that we should not take alternative voices as of the other polarity, as devils of temptation.

"Intention" and "temptation" both have the same metaphor of a pull between the self and the prospect, like the pull of a rope that holds a tent. The difference is in which end the pull seems exerted from: in "intention" it's the self that pulls; in "temptation" it's the prospect. Prior to such polarization, it can just be experienced as a pull, a felt attraction, an inviting glow, it "sounds good."

If the natural use of consciousness is to hold an array of prospects ("con-scious" comes from "together, see") before our combined senses, until we come to enough clarity of vision to resolve on our best course, then settling for the first prospective voice that resembles us, taking that as our both our boss and free will, precludes our reaching the more mature, fuller resolution. This places vision and feeling in an inferior position to language in creating our path.

In English, and generally in European languages, "to know" is "to see," not "to say" or "to hear" (SWEETSER, 1990). We don't know unless we see it, both in the sense of seeing with our eyes, and in the deeper sense of seeing it with our intellect or our intuition or our feelings. We have all had the experience of saying something without really seeing it. So there's a difference in that way, sometimes, between merely saying, and deeply seeing. Seeing is arguably of at least equal importance to knowledge as saying. Arnheim (2004) 
argues it is more important. In any case, to slight visions for words, rather than grant them equivalent epistemic and ontological stature, may be unjustified.

Pereira Jr. (2018, p. 213) speaks of cognition "according to logical rules and using a language (verbal or imagery)" (emphasis in original). His picture is consistent with thought in words and imagery, while "elevated to a conceptual plane," (PEREIRA JR., 2018, p. 214) having as their common "presentational domain" (PEREIRA JR., 2018, p. 210) the projected, or "extended conscious domain (ECD)" (PEREIRA JR., 2018, p. 209). Logical rules then, whether derived from metaphor and analogy (LAKOFF; JOHNSON, 2003), inborn like a hypothesized Chomskian grammar (FODOR, 1975; JACKENDOFF, 1994), or otherwise based, support the "apprehension and comprehension of concepts" (PEREIRA JR., 2018, p. 212-213) using each and every sort of imagery, whether audible, visual, or perhaps of other senses. Since the various sensory imageries are handled by the same underlying capacities - and even can be mixed in use - it is natural to assume they share a common field, a projective ECD. Public language imagery is powerful, but does not stand alone there.

\section{THE SECOND PARADOX AND ITS DISCONTENTS}

The title of this paper refers to "two paradoxes." The first is Velmans' paradox, of how the world can be both before us, and within us. The second is the paradox of how language can lead us well and effectively, if language is taken to sometimes occur truly spoken by an inner voice, a homunculus, separable from projections of prospective speaking. The paradox is that for such a voice to lead us, it must be ahead. So the question is, is it to be ahead separately from our other projections, ignorant of their potential contributions to it, or are its auditions to be commingled with the other senses' projections, into vision and feeling for the future? In Gendlin's (1998) clinical practice of "focusing," what he sees as the three primary senses, seeing, hearing and feeling, are to be brought into a common alignment. Hutcheson (2004) similarly held that our various outward senses combine to form what he called the "inward sense," for him the key to moral orientation towards virtue and beauty. Hutcheson saw symmetry as central to our appreciation of each; it is epistemic symmetry in how we take the projections of the several senses I argue in favor of.

Many of us take the language we imagine, some of it anyway, to be really spoken in the mind, to really represent a speaker which is some part 
of us within. In this imagination of audition, we believe we find evidence of ourselves, as if we were overhearing ourselves. By contrast when we imagine visual things, even if we are imagining how we ourselves look, we do not take that as being in the same epistemological category, the same direct evidence of self. We thus privilege hearing ourselves over seeing ourselves; we reify the speaking self. We might even take it as an ontological fact that we have an inner speaker, an ego of that sort; in a way where we do not take ourselves to have an inner seer, or dancer. Language stands apart and alone, in this schema.

In Freud's (1923) theory of neurosis, the cure is in enabling other "contents" to take on word representations. This may more easily be done when language is not held apart, projected into a presumed homuncular space held separate, to be uniquely followed, rather than into the shared futures projected in the blended senses, in which space it may be more freely associated.

Aristotle, in his Ethics (1962), contrasted the moral strategy of seeking to be contained by one's opinions, which he called the enkratic approach, with the approach of wisdom, or the sophronic strategy, based on a balanced tempering between attractions. In his view the strategy of containment by opinion inevitably fails, leading to weak will, akrasia. This finds a later Chinese echo in Lu Chi's (1987) claim, "When the mind is caged and separate, the spirit wanders, and nothing is controlled." In Freud's (1923) metapsychology, the received opinions of our culture form the "superego," which the I is healthier once freed from.

Chuang Tzu (1970), whose central concern was the relation of language to finding the best ways ahead ("tao" being the plural as well as singular form in Chinese (HANSEN, 2000), recommended: "Let your ears and eyes communicate with what is inside, and put mind and knowledge on the outside. Then even gods and spirits will come to dwell, not to speak of men!" This can be read to suggest we had best project linguistic prospects out beyond our sensed awareness of the present scene, and take as our center that present awareness, with prospective words out beyond presence, rather than at the core.

Intentions formed through a more balanced use of all the senses from the outset, intentions formed with full participation of vision, feeling, indeed the body, don't lead to the same suffering as intentions formed primarily through language, with vision and feeling largely left out. This is a problem for all sorts of ideologies and doctrines, that they are sets of opinions the ego can 
incorporate, and is supposed to proceed from despite contrary signals from the senses, the body, and our dreams. This may be why even the best-formed and intended doctrines and ideologies lead so many people to suffering.

In conclusion, there are prospects anchored in present sensation, and prospects which are more purely invention and conjecture. A common mistake made of the "inner voice" is to consider it to be within the sensory horizon - to be known as we know things which are present to the senses, and then to treat it not as a possible voice but as a real one, an epistemic shortcut to self-knowledge, when instead it leads to prematurely foreclosing our imagination, from whose fuller scope better self-reflection, and better discovery and creation of prospects, might well emerge. Better that we place all projections, including of voices, into the same forward category, than that we paradoxically put a subset of opinions, of things that may be said, into a category of their own, also put forward so they may lead us, but isolated from and polarizing of the rest of imagination, opinions without vision, untempered by the broader scope of our senses.

BLAUVELT, W.; MUNDELL, C. Dois paradoxos da projeção. Trans/Form/Ação, Marília, v. 41, p. 183-198, 2018. Edição Especial.

Resumo: Os modelos projetivos de consciência e de seus conteúdos, recentemente desenvolvidos, desafiam os esquemas tradicionais, nos quais todos os conteúdos da consciência são mantidos bem contidos dentro do crânio. Trabalhando desta forma, a partir de vários ângulos, torna-se evidente que existem inconsistências na forma como emolduramos classes de conteúdos mentais que são possivelmente equivalentes em seu ser. Exemplos particulares de imagens, de dança e de palavras são apresentados para ressaltar o choque em nossas suposiçóes apreensivas, focalizando possíveis custos cognitivos e psicológicos de tal inconsistência. Uma maneira coerente de misturar os esquemas do "continente" e do "projetor" é apontada; no entanto, tal combinação não suporta as exigências gerais, encontradas na literatura, para qualquer tipo de fala puramente interna, que esteja contida, mas náo projetada. A reflexão consciente pode, em todos os casos, depender da projeção, com reflexo na imagem - visual, audível, até tátil e sentida - situada apenas no lado distante do que pode ser esquematicamente compreendido como o horizonte sensorial onde, no espaço-tempo e agora, nossas expectativas imaginativas apóiam o reconhecimento das coisas presentes e atuais.

Palavras-Chave: Consciência. Projeçâo perceptiva. Imagem. Dança. Palavras. 


\section{REFERENCES}

ARISTOTLE. Nichomachean ethics. Translation by M. Ostwald. Indianapolis: BobbsMerrill, 1962.

ARNHEIM, R. Visual thinking. Berkeley, CA: University of California Press, 2004.

BECK, A.T. Cognitive therapy and the emotional disorders. New York: Penguin, 1979.

BLAUVELT, W. Y's Domain. In: LIBET, B.; FREEMAN, A.; SUTHERLAND, K. The volitional brain. Thorverton, UK: Imprint Academic, 1999. p. 269-274.

LU CHI. Wen Fu: the art of writing. Translation by S. Hamill. Portland, Oregon: Brettenbush Books, 1987.

CHUANG TZU. The complete works of Chuang Tzu. Translation by B. Watson. New York: Columbia University Press, 1970.

CLARK, A. Surfing uncertainty: prediction, action and the embodied mind. Oxford: Oxford University Press, 2016.

DESCARTES, R. Meditations on first philosophy. Cambridge, UK: Cambridge University Press, 2017.

FAUCONNIER, G. Mappings in thought and language. Cambridge, UK: Cambridge University Press, 1997.

FERNYHOUGH, C. The voices within: the history \& science of how we talk to ourselves. New York: Basic Books, 2016.

FODOR, J. A. The language of thought. Cambridge, MA: Harvard University Press, 1975.

FREUD, S. The Ego and the Id. London: Hogarth, 1923. (Standard Ed. Vol. XIX).

GENDLIN, E. T. Focusing-oriented psychotherapy: a manual of the experiential method. New York: The Guilford Press, 1998.

GIBSON, J. The ecological approach to visual perception. New York: Psychology Press, 2015.

GREENBLATT, S. The rise and fall of Adam and Eve. New York: W.W. Norton \& Company, 2017.

HANSEN, C. A daoist theory of Chinese thought. Oxford: Oxford University Press, 2000.

HOFSTADTER, D.; SANDER, E. Surfaces and essences: analogy as the fuel and fire of thinking. Philadephia: Basic Books, 2013.

HUTCHESON, F. An inquiry into the original of our ideas of beauty and virtue. Ed. W. Leidhold, Indianapolis: Liberty Fund, 2004.

JACKENDOFF, R. Patterns in the mind: language and human nature. New York: Basic Books, 1994. 
JOHNSON, M. The body in the mind: the bodily basis of meaning, imagination, and reason. Chicago: The University of Chicago Press, 1987.

LAKOFF, G. Women, fire and dangerous things: what categories reveal about the mind. Chicago: University of Chicago Press, 1990.

LAKOFF, G.; JOHNSON, M. Metaphors we live by. Chicago: University of Chicago Press, 2003.

NEWTON, N. Foundations of understanding. Amsterdam: John Benjamins, 1996.

PEREIRA JR., A. The projective theory of consciousness: from neuroscience to philosophical psychology. Trans/Form/Ação, v. 41, n. especial, 2018, p. 199-232.

REID, T. An inquiry into the human mind on the principles of common sense. Edited by D. Brookes. Philadelphia: Penn State University Press, 2000.

RYLE, G. The concept of mind. New York: University Paperbacks, 1949.

SEARLE, J. Speech acts: an essay in the philosophy of language. Cambridge, UK: Cambridge University Press, 1970.

SWEETSER. E. From etymology to pragmatics: metaphorical and cultural aspects of semantic structure. Cambridge, UK: Cambridge University Press, 1990.

VELMANS, M. Goodbye to reductionism: complementary first and third-person approaches to consciousness. In: STUART, R. et al. (ed.). Toward a science of consciousness. Thorverton, UK: Imprint Academic, 1996. p. 45-52. (Consciousness Research Abstracts).

WILEY, N. Inner speech and the dialogical self. Philadelphia: Temple University Press, 2016.

Recebido: 15/11/2018

Aceito: 15/11/2018 
BLAUVELT, W.; MUNDELL, C. 